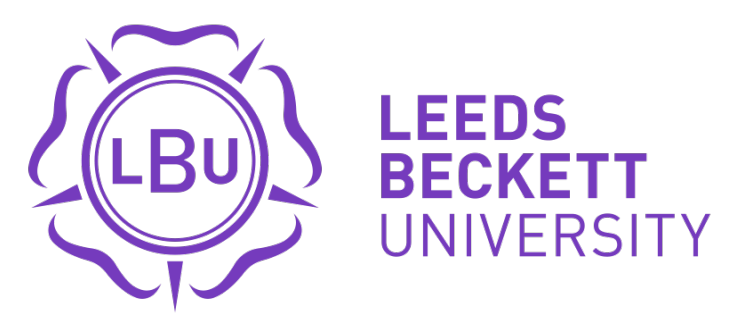

Citation:

Fletcher, T (2011) "Aye, but it were wasted on thee": Cricket, British Asians, ethnic identities, and the 'magical recovery of community'. Sociological Research Online, 16 (4). DOI: https://doi.org/10.5153/sro.2468

Link to Leeds Beckett Repository record:

https://eprints.leedsbeckett.ac.uk/id/eprint/2315/

Document Version:

Article (Updated Version)

The aim of the Leeds Beckett Repository is to provide open access to our research, as required by funder policies and permitted by publishers and copyright law.

The Leeds Beckett repository holds a wide range of publications, each of which has been checked for copyright and the relevant embargo period has been applied by the Research Services team.

We operate on a standard take-down policy. If you are the author or publisher of an output and you would like it removed from the repository, please contact us and we will investigate on a case-by-case basis.

Each thesis in the repository has been cleared where necessary by the author for third party copyright. If you would like a thesis to be removed from the repository or believe there is an issue with copyright, please contact us on openaccess@leedsbeckett.ac.uk and we will investigate on a case-by-case basis. 
"Aye, but it were wasted on thee": Cricket, British Asians, ethnic identities, and the 'magical recovery of community'.

\begin{abstract}
People in sport tend to possess rather jaded perceptions of its colour-blindness and thus, they are reluctant to confront the fact that, quite often racism is endemic. Yorkshire cricket in particular, has faced frequent accusations from minority ethnic communities of inveterate and institutionalised racism and territorial defensiveness. Drawing upon semistructured interviews conducted with amateur white and British Asian cricketers, this paper examines the construction of regional identities in Yorkshire at a time when traditional myths and invented traditions of Yorkshire and 'Yorkshireness' are being deconstructed. This is conceptualised through a reading of John Clarke's 'magical recovery of community'. Although cricket has been multiracial for decades, I argue that some people's position as insiders is more straightforward than others. I present evidence to suggest that, regardless of being committed to Yorkshire and their 'Yorkshireness', white Yorkshire people may never fully accept British Asians as 'one of us'. Ideologically and practically, white Yorkshire people are engaged in constructing British Asians as anathema to Yorkshire culture. The paper concludes by advocating that, for sports cultures to be truly egalitarian, the ideology of sport itself has to change. True equality will only ever be achieved within a de-racialised discourse that not only accepts difference, but embraces it.
\end{abstract}

Keywords: British Asians; Community; Cricket; Identity; Racism; Symbolic Boundaries

\title{
Introduction
}

Yorkshire typifies 'northern-ness' and emphasises a unique type of 'Englishness' (Author 2011c). The people of Yorkshire are immensely proud of their county and culture and, it has been suggested, they identify more strongly with their county than they do with their country (Russell 2004). Naturally regional pride is not unique to Yorkshire. Devon, the Welsh Valleys, the Scottish highlands, Liverpool and Manchester - to name but a few - all have a very strong sense of their own identity (Allen 2008). Many people have attempted to write about Yorkshire, Yorkshire people and Yorkshire cricket (Birley 2003; Light 2009; Marqusee 1994; Russell 1996; Stone 2008; Wagg 2003/04). However, rather than undertaking empirical research, they have tended to focus on secondary evidence, which deifies already existing cultural stereotypes. Where analyses of Yorkshire have been conducted, they have (intended or otherwise) produced a de-racialised subject within which white racism disappeared. ${ }^{1}$ What has been missing is an examination of the inherently racialised elements of Yorkshire culture and 'Yorkshireness' and how these affect minority ethnic communities' experiences of playing and belonging to the game in the region.

I begin this paper by examining a number of common stereotypes of Yorkshire culture and Yorkshire people. Next, in light of contemporary social changes, I explore whether these stereotypes possess any contemporary relevance. Finally, I locate the role of the Yorkshire cricket leagues and Yorkshire County Cricket Club (YCCC)'s 'birthright policy' in the historical exclusion of South and British Asian communities. ${ }^{2}$ Through a reading of John Clarke's (1976a) conceptualisation of the 'magical recovery of community', Yorkshire culture does this through an emphasis on symbolic territorial defensiveness which, ideologically and practically, positions South and British Asian 
communities as anathema to Yorkshire. I conclude by advocating an overall change in sporting ideology in terms of how the inclusion of ethnic minorities is negotiated.

\section{A changing Yorkshire?}

Over the last half century, Yorkshire's 'indigenous' working class white community has been transformed. During the post Second World War and post-colonial periods Britain needed cheap labour to facilitate national recovery. Directly related to British colonial rule on the Indian subcontinent and Caribbean, families from these regions were encouraged to move to Britain to fulfil this need (Kalra 2000). Due to its burgeoning industries, Yorkshire was a popular settling place for diasporic communities - particularly poor, mainly uneducated (Muslim) Mirpuris (Ballard 1994). Sheffield's steel industry and Bradford's textile mills and factories in particular, proved fruitful for many South Asian settlers (Kalra 2000). According to the population census in 2001, Yorkshire and the Humber region was home to 146,330 residents of Pakistani origin (Office for National Statistics 2001). Of that number, 15,844 are resident in Sheffield $-3 \%$ of the city's total population. As is common throughout UK cities, Sheffield's minority ethnic communities tend to be concentrated in specific enclaves. Residents of the suburb of Sharrow (to the south-west of the city) for instance, represent 39\% minority ethnic communities (ibid.). It is interesting that while Yorkshire has changed dramatically over the last century, popular perceptions of the region, its attendant culture and history have remained relatively stable.

Since the 1970s the traditional industries that were so important in the evolution of Yorkshire's identity have been in a constant state of decline. The steel works in Sheffield, textile mills in Bradford, not to mention, the ubiquitous coal pits have all petered out into melancholic insignificance. This had a dramatic effect on how Yorkshire's predominantly white communities perceived themselves and others. In his discussion of declining dockland industries in London's East End post World War II, Jack Fawbert (2011: 180) identifies how almost exclusively white cockneys experienced a 'deep and profound sense of cultural loss'. In both Yorkshire and the East End at that time, it was felt that the increasing migration of diasporic communities challenged the coherency of their regional identities. In neither case did the insecurities brought about by these changes lead to an overall decline in these communities; rather they stimulated an increasingly sustained sense of 'topophilia'. Therefore, the shifting idea and decreasing national relevance of 'Yorkshireness' would go some way to explaining why many people associated with Yorkshire cricket are so defensive over 'their' traditions, heritage and territory. This reaffirmation of collective identity reflects what Clarke (1976a) refers to as the 'magical recovery of community'.

\section{'Tha not from rarn'd ere are ya?' Defining Yorkshire's boundaries of belonging through the lens of John Clarke}

Members of Yorkshire culture use cricket as a means of expressing social identity, which is shaped by a strong sense of, and attachment to, their ethnic community. Although living in a different time and in a different place, the resonances with the skinheads, as discussed by Clarke (1976a), are clearly identifiable. Clarke's work examines the skinheads as a working class subculture, and argues how 
identification with the subculture allowed the skinheads to challenge their exclusion in post-war Britain. Clarke cites the usual antagonisms between the skinheads and institutions of authority, such as the work place and school. However, Clarke also refers to the skinheads' sense of exclusion from, and subsequent resentment towards, people from their own social background who were compliant with the oppressive 'system' (Hughson 1997).

From Clarke's perspective resistance exists in the symbolic use of culture by youth 'as a source of collective struggle' against institutions of authority and rival (or unwanted) community groups. As Hughson (1997) has previously argued, Clarke's interpretation of community lends itself well to Anderson's (1983) notion of the 'imagined community'. The skinhead 'imagines' himself to be the proprietor of a particular way of life - a way of life that was threatened by the 'social readjustment' brought on by post-war capitalism in Britain (Hughson 1997: 240). The conceptualisation of the 'magical recovery of community' places an emphasis on symbolic territorial defensiveness. Clarke argues how, when one's community identity is under threat, community members may attempt to recreate, through symbolic manifestations, a sense of their traditional cultural identities as a substitution for its 'real' decline. This point is crucial to understanding Clarke. A 'real' notion of community relies on the principle of solidarity, and Clarke argues that working class solidarity was lost in the post-war period. Instead of being part of a community literally, the skinheads were forced to live out an 'image' of the community, and rediscover their relationships through 'stylistic ensembles', such as conflict (Clarke 1976b: 181). Thus, the themes and imagery of the skinheads still persisted, but their reality was in a state of 'decline' and 'disappearance' (Clarke 1976a: 100).

Clarke (1976b: 180-181) makes the point that a group's 'self-image' is formed 'not simply through the internal processes of the group' but in relation to 'significant groups of others'. Groups are likely to define their 'boundaries of membership' as a reaction to 'Other' groups which, at least in terms of age, gender, 'race'/ethnicity, residence or leisure pursuit (amongst others), inhabit the same subcultural arena. The hostility of the reaction against the Other will vary between subcultural groups. Clarke describes a number of conflicts the skinheads were involved in, including 'gang battles' (especially with 'Hippies') and 'Paki-bashing' (a violent response towards the movement of South Asians into working class localities). Similar conflicts are evident in sport between rival supporter groups. In the case of football, the skinheads would routinely target rival supporter groups (often other skinheads) with boisterous and violent behaviour (Clarke 1973). Hughson et al. (2005: 80) explain this as an attempt by the skinheads to 'claim kudos within the stakes of masculinity'.

In no way am I suggesting that members of the Yorkshire cricket community involved in this research be viewed as a subculture in the way described by Clarke. Given their formal participation in, and support for the game, the inhabitants of this community appear almost antithetical to the politics of the subculture. What I am arguing is that the changes (social, cultural, economic) that have occurred in Yorkshire in the post-war period have led to a reassertion ('magical recovery') of traditional forms of Yorkshire identity amongst this community in a similar way to that conceived by Clarke. However, rather than being engaged in the violent and 'spectacular' forms of social identity formation described by Clarke, the respondents in this research instead exhibited more ordinary 
displays of social identity formation. In saying this, the Yorkshire identity referred to is contested; not necessarily in terms of what it represents, rather in terms of who has the right to access it.

\section{Why study cricket in Yorkshire?}

In this paper I focus on league cricket in Yorkshire and the varying interplays of local and social identity therein. League cricket embodies a distinctive culture compared to the professional game (Author 2011c). Neither form of the game is fundamentally different to the other in terms of structure or format. However, according to Russell (2004: 236), league cricket takes on particular importance because of its ability to 'dramatise' and 'symbolise' the supposed aspirations, characteristics and values of one territorial unit. Given the massive structure of league cricket, its partisanship and overall success across England, it has been rightly suggested that, in addition to the international and county scenes, league cricket requires more substantive academic attention (ibid.). ${ }^{3}$

There has been an historical lack of sociological inquiry into specific cricket cultures; meaning the voices, experiences and needs of ordinary cricketers in Yorkshire have been neglected. Existing sociological research into 'race' and cricket has focused predominantly on the excluding and alienating effects of 'Englishness' in international cricket (Malcolm 2009), issues of identity and problems of racism in amateur cricket (Long et al. 1997b; McDonald and Ugra 1998), or articulations of fandom within diasporic communities (Author 2011b). At the current time, very little research exists that directly focuses on the experiences of British Asians in cricket (cf. Author 2011a, 2011c; Burdsey 2010a, 2010b). ${ }^{4}$ The relationship between British Asians and sport generally remains a relatively under-researched and misunderstood area of sociological inquiry when compared to other ethnic groups - for example, Black African Caribbean (cf. Burton 1991; Carrington 1998, 1999). It continues to be the case that dominant histories of the sport in England have centralised white voices. Subsequently, the experiences and stories of minority ethnic players and clubs - and in particular, how they have interacted with white spaces - remain heavily marginalised. This paper goes some way to address this.

The data used in this paper were collected during research conducted between June 2007 and January 2010. The fieldwork was undertaken with two culturally contrasting, high level amateur cricket clubs in Sheffield, South Yorkshire. Both clubs and all respondents have been given pseudonyms. ${ }^{5}$ The first club, 'Sutherland', is locally acknowledged to be 'white'. The second club, 'Aylesworth', although not an 'Asian' club in the strictest sense because it has white members, fielded only one white player (infrequently) in the first team between 2005 and 2010. It is important to note that during the research period, the Sutherland club was where I participated as a player. I was also familiar with the Aylesworth club, having participated against the club at both junior and senior levels. Due to my familiarity with each club and the leagues they participate in, I had expert knowledge of the fields. Therefore, I operated with a degree of freedom as to whom and what was examined and, in adopting this technique, I was able to construct a sample that satisfied the needs of the research. In saying this, using purposive sampling raises critical questions over subjectivity and whose voices were heard in the research and whose were not. 
Having a personal relationship with the white participants has been an essential feature of this research. Sport represents a particularly pertinent field in consideration of over-identification because researchers of sport are invariably passionate followers (though not necessarily participants) of sport. As Hughson et al. (2005) warn; there is a fine line between identification and over-identification. Working with people who were familiar to me (namely participants from the Sutherland Club) posed a number of ethical challenges, which I have discussed elsewhere (Author 2010). None was harder than adopting a consistent approach to dealing with incidences of racism. During fieldwork I witnessed a number of racist incidents (mainly coded jokes) - perpetrated by members of the Sutherland Club who I considered to be my friends. On many of these occasions (even in spite of the fact that I am committed to racial equality) I chose not to 'out' these individuals as racist. In this regard, being familiar with certain respondents was debilitating; as instead of drawing attention to racist behaviour, I chose to respect our friendship (thereby not compromising my position as a researcher), and continued my research journey. I recognise how this choice is ethically questionable particularly given commitment to working with the British Asian participants to reduce racism within the cricket. However, throughout the duration of this research I had to juggle a number of different identities and roles - some of which were conflicting (Reinharz 1997). With Sutherland, I was a 'player', 'friend' and 'researcher', whilst with Aylesworth, I was a 'stranger', 'researcher', 'story teller' and eventually, a 'friend'. Most importantly, in both situations, I was a 'cricketer' and, I believe, this role was my most successful.

Despite the apparent 'convenience' of undertaking work with these clubs, I had a clear rationale. Sutherland was selected due to its position within an area of Sheffield renowned for the size of its minority ethnic communities (37\%) and for its conspicuous lack of ethnic minority membership. Aylesworth was selected because of the cultural 'shift' that has taken place within the club over the last decade. Aylesworth was never intended to be a club exclusively for people of South Asian descent. Aylesworth was already an established club when migrants began to settle in the area. In fact, it is only since the turn of the century that Aylesworth has begun to attract disproportionate numbers of players of South Asian descent. Aylesworth's rapid evolution, and due to the fact that it is unlike many other 'Asian' clubs because it continues to participate in an otherwise 'white' league, makes it a salient example to study.

The research involved a process of in-depth ethnographic fieldwork based on 21 semistructured individual interviews, two focus group interviews and participant observation. Where possible, I attended and participated in matches, training sessions and social gatherings. Sutherland accounted for thirteen individual interviews and Aylesworth eight individual and two focus group interviews. In total, 31 people were interviewed for the research: twelve were white and nineteen were British Asian. The majority of the British Asian respondents were British-born, although a small number had migrated to Britain from the Indian subcontinent. They occupied diverse occupations from management and teaching to taxi drivers and restaurateurs. Most identified themselves as Muslim, while a small, predominantly younger group, cited no religious affiliation. ${ }^{6}$

\section{Living with and through the myths and invented traditions}


Evidence from this research suggests that, while people are aware of Yorkshire's myths and traditions, they do not necessarily believe them and certainly do not live by them. Regardless, all the white respondents from the Sutherland club identified how they had been socialised into believing Yorkshire's myths and invented traditions (Hobsbawn and Ranger (1992[1983]) were innate and natural and thus, being from Yorkshire was something to be proud of. As Jeff (32, sport development officer) said:

'The idea of being from Yorkshire is almost biological. It's something you're told to be proud of. You're brought up to believe that, to be 'Yorkshire', is to be a certain way. It's something different from everywhere else.' (Interview, February, 2009)

John Clarke (1976a: 101) argues how youths in particular, inherit cultural traditions from their 'parent culture'; that is, the dominant culture at the time and, as in Jeff's testimony, the aspects of culture embraced so fondly will often be those which refer to a community's self image in relation to others. Due to its history and visibility in Yorkshire culture, cricket continues to be an important aspect of defining Yorkshire's identity - both inside and outside its boundaries. This view was reflected by Sutherland's Lynn (23, psychologist) in his discussion of playing cricket in Australia:

Lynn: When I arrived in Australia I was greeted with fish and chips and a cup of tea. I'm not lying. I'm surprised it wasn't Yorkshire Tea, [he laughs]. They had summed me up simply by knowing where I came from.'

TF: 'How did that make you feel?'

Lynn: 'I was a bit embarrassed, but at the same time, it was good. I had been worried they weren't going to get me ... my 'Yorkshireness' ... I think they enjoyed it'. (Interview, October, 2008)

In research conducted examining cricket's regional identities in Yorkshire and Surrey, Duncan Stone attempts to trace the emergence of this kind of stereotyping and to what extent they are (using Stone's terminology) 'real' or 'imagined' (Stone, 2008: 501). Stone's research suggests that a unique and homogenous perception of Yorkshire has been 'accepted' by Yorkshire people and people from other cricketing counties. He argues that, due to common myths, people from other counties have fixed impressions of what Yorkshire people are like. Stone provides a perceptive analysis, however, his conceptualisations rely too heavily on myth and imagination, and depict Yorkshire and its people in an essentialised way. There is also a failure to take into account the complexity of the identity constructing processes, and the numerous social, cultural and political processes (including globalisation and migration), which have a bearing on these identities. There is also a tendency to assume that, by deconstructing the origins of social identities, coupled with contemporary analyses of those identities, some 'real' and essential identity will emerge. ${ }^{7}$ 
Yorkshire - socially, culturally and politically - has experienced rapid change since the latter half of the twentieth century. Once believed to be a beleaguered, backward and grimy region, Yorkshire now epitomises a globalised, cosmopolitan and, some would argue, postmodern region (Bramham and Wagg 2009). Its heavy industries have all but disappeared - having been replaced by restaurants, bars, nightclubs and countless shopping malls (ibid.). Thus, the Yorkshire culture known and embraced so fondly by previous generations has evolved beyond essentialist depictions, as described above. Sutherland's Gary (retired school teacher) spoke of the dwindling significance of Yorkshire identity amongst younger generations and reflected with a degree of regret that young people were less inclined to protect the culture and traditions people of his generation had been so proud of:

'I don't think the pride I grew up with exists anymore. I don't think the youngsters have that. I think it's almost gone, except for people like myself. I don't think that a strong sense of Yorkshire identity is passed down through the generations anymore'. (Interview, February, 2009)

A parallel can be drawn here with Clarke's notion of the 'magical recovery of community'. For Clarke (1976a: 99) 'skinhead culture selectively reaffirms certain core values of traditional working-class culture'. Gary's comments can be seen to work similarly in accordance with a perception of traditional Yorkshire culture. Most significant perhaps, is how the skinheads are seen as engaged in a 'recreation of community' which, beyond the level of social identity they create, is a lost cause, because the type of working-class community they seek has disintegrated. Gary's invoking of tradition, therefore, might be another example of a 'magical recovery' in that, the Yorkshireman (gendered nomenclature intended) ${ }^{8}$, like the skinhead, imagines himself as a community member to be the true heir of a traditional way of life forsaken by other Yorkshiremen.

The way of life described by Gary is now less relevant because the version of 'Yorkshireness' referred to no longer exists - or at least, has evolved into something different. Indeed whatever purchase the baleful Yorkie masculinity of the past has on the life of contemporary Yorkshire, there is now very little public acknowledgement of it (Wagg 2003/04). The irony for traditionalists such as Gary therefore, is that, the community they are attempting to recover is irrelevant in the time it is intended for. As a result we must think beyond the creating of such myths towards a better understanding of how cultures (including sports) are created, imposed and internalised (Hughson 2009).

Gary's testimony was important because he was amongst a small minority of respondents who acknowledged how myths of Yorkshire had been consciously created in order to establish an imagined community of 'Yorkshireness' (Anderson 1983). However, he acknowledged that not everyone in the region has access to this community. Developing on from this point Sutherland's John (26, school teacher) reflected that belonging to a cultural region is something that runs in the blood' and therefore, is by definition, exclusionary: 
I think both of these identities (northern and Yorkshire) come with certain values ... I think you are born into that. I don't think you can move to Yorkshire or somewhere else in the north and then, in a couple of years say, "I'm a northerner". You can't ... learn it. I think being born into it is the only real route to being a northerner or Yorkshireman'. (Interview, October, 2008)

Categorisations of Yorkshire and, in particular, how conceptualisations of being 'one of us', can become quite contentious when dealing with people who are fundamentally cultural 'Others'. Aylesworth's Hamza Ilyas (33, engineer) was convinced that his 'Asianness' was fundamental (rather than a hindrance) to his 'Yorkshireness':

'I'm British, I'm Muslim, I'm Asian and I'm from Yorkshire. I also eat fish and chips [laughs]. Does that mean I'm a Yorkshireman? I have a set of values that I have developed through my life ... I don't steal, I don't intentionally hurt anyone, I respect my fellow man ... and I'll tell you, they're all Yorkshire, but they're the same values that people live by in Kashmir and the Punjab. And these values are what make me, me. But which of those values makes me non-Yorkshire? People who make judgements like “you're Yorkshire, but you're not" are narrow-minded and racist.' (Interview, December, 2008)

According to Hamza Ilyas we are still unable to halt the flow of folk concepts and definitions that maintain the hegemonic structures and racist ideologies that surround Yorkshire. Stuart Maconie (2008) argues that Yorkshiremen actually cherish their prejudices; in that, they reaffirm a traditional form of 'collective solidarity' (Clarke, 1976a). Nevertheless, Sutherland's Alfie (28, marketing manager) urged people - specifically those who go out of their way to negatively caricature the region - to present a more positive and authentic image of Yorkshire, as opposed to the contrived, overly stereotypical and satirical images which so often predominate:

'I'm proud of being a Yorkshireman. This is part of who I am. I don't think you get that pride in other counties. I think people should look at our pride and see it as a good thing. But most people don't ... they just take the piss'. (Interview, October, 2008)

Alfie later spoke of his belief that Yorkshire's changing image is both positive and necessary, but also acknowledged how there are others who lament the changes and try instead to cling on to (or recover) some sense of tradition by refusing to adapt to the changing environment. This hankering after tradition was shared by Sutherland's Jeff who reflected on the general significance of sport to the heritage of northerners:

'I think sport all goes back to that working class culture and the fact that it didn't cost a lot. People liked to play and follow sport. I guess, for many, sport was their life because 
traditionally, you got up and went to work - whether down the pit or the steelworks and what you looked forward to was going to the match on a Saturday or playing cricket or football and going to the pub. These are the things that make the relationship between northerners and sport stand out'. (Interview, February, 2009)

Jeff's depiction of sport as an escape route from the harshness of urban northern working class life is hard to ignore. Keith Sandiford (1998) argues how historically, cricket in northern England was about 'much more than two teams having fun with bat and ball'. Instead, in the wake of the cotton slumps of the 1860s, the character of northern cricket was a reflection of the 'harsher realities' of working class life (ibid: 25). Thus, for the northern working class, cricket facilitated their individual and community identities.

Whilst this distinctive culture united many of Yorkshire's communities, in many ways it also acted to disassociate Yorkshire from other county communities. Cricket in the north has often been characterised as a resistant format to that of the 'real' game played in the south (Russell 1996, 2004; Stone 2008). Yorkshire cricket was deemed by cricket's administrators to be too competitive and overly aggressive. ${ }^{9}$ It was identified early that YCCC was principally interested in competition and stamping its superiority by winning - a characteristic which was not immediately accepted by purists of the game who preferred to promote the game's morality (Williams 1999, 2009: 512). According to Sandiford (1998), critics feared that sportsmanship suffered when cricket was played too seriously. Thus, by the start of the twentieth century, 'Yorkshire cricket had come to represent a set of meanings that clearly contradicted many of the values which dominated the game elsewhere in the country' (Light 2009: 502). Ramachandra Guha (2002: 53) reflects on the north/south divide using a Yorkshireman to illustrate:

'A lovely story tells of an elegantly dressed Oxford undergraduate being bowled first ball by an ex-miner from Yorkshire. When the batsman, en route to the pavilion, complimented the bowler on the delivery, the answer he got was "Aye, but it were wasted on thee".'

Sutherland's Tony (26, teacher) also reflected on this imagined competitive Yorkshire identity using YCCC fast bowler Fred Trueman to illustrate:

'My grandad always talks about Trueman with admiration. Apparently Trueman was a nasty bastard and people feared him for it. My grandad was at Headingley (YCCC's home ground) one day when Trueman broke someone's foot when he was bowling. Now in those days it was probably sporting for the bowler to say "sorry" and see how the bloke was. But Trueman apparently responded by saying: "shut up, or I'll break your other foot as well'”. (Interview, February, 2009) 
While people in the south have frequently depicted the north as an unwanted cultural Other, most respondents (mainly white) involved in this research, viewed the north as being at the epicentre of English cricket and constructed the south as its inauthentic, 'softer' relation. Sutherland's John for instance, said:

'Every southerner I've ever met playing cricket has been a posh wanker ... they have no heart. They're all like [mimicking a southern accent] "there you go old chap", whereas us northerners are like, "come on ya bastards." We play it hard and proper'. (Interview, January, 2009)

Yorkshire cricket became the 'Other' of English cricket because it was different, resistant, and antiestablishment and for many Yorkies, these characteristics made Yorkshire cricket superior. Significantly, this is something many people in Yorkshire remain proud of and, in many ways, are keen to see a return to.

In his study of rugby league, for instance, Karl Spracklen (2001: 74) contends that the myth of northern supremacy creates a 'fictive ethnicity'; an exclusiveness created by the symbolic boundaries and invented traditions of the imagined community: 'This sense of northern identity is seen as a source of strength for traditionalists, who see the relationship as natural and unassailable, and an articulation of their own sense of personal and social identity'. Sutherland's Jeff brought to light that an important characteristic of being a Yorkshire person is appreciating where you come from appreciating one's roots, and protecting that identity. Indeed, according to Clarke (1976a, 1976b), one of the most crucial aspects of community is the emphasis placed on solidarity. Jeff was honest about having relocated from the north east of England to Yorkshire where he has a successful job and fluid social mobility, but maintained he was still as 'northern' as ever. It was important to Jeff that he belonged to the legacy of Yorkshire and his championing of sport was indicative of this:

'My family is very much scattered around the country. My uncle and his family are still up here, but my dad and my brothers moved down to [Place] a long time ago. So when I was growing up I took on board northern traditions from my uncle rather than the culture my dad was living in ... I wanted to retain that; regardless of whether my dad and brothers did. I was kind of a black sheep really because I wanted to retain those aspects of life associated with the north ... like going to the football and watching the cricket'. (Interview, February, 2009)

Spracklen (2001) contends how the images described by Jeff (and others) do not stand in isolation - they are inextricably linked to ideas of region, masculinity, power, and exclusion. These images are used to justify implicitly the symbolic boundaries of the imagined community that lets in those who resemble the images, but excludes those who do not (ibid: 73; Cohen 1985). This point is particularly relevant here, given that, throughout its history, YCCC has been accused of restricting the participation of minority ethnic communities. 


\section{Yorkshire CCC's birthright policy and the 'magical recovery of community'}

YCCC's birthright policy restricted participation for the county team to those people born within the county's boundaries until 1992. For many critics, the 'birthright' policy was thought to be at the heart of the club's racist and exclusive reputation (Searle 2001). As I have argued elsewhere, the long-standing failure to field minority ethnic players in the first team with any real consistency is demonstrative (for many) of ingrained racism within the club, and although the policy's strictness was never sacrosanct, it added to the perception that the club did not welcome 'outsiders' of any description (Author 2011a, In press). For YCCC, achieving success with native talent became a point of honour as glories could be attributed to an alleged regional superiority, and arguably reflects an example par excellence of a defensively organised collective (Clarke, 1976a). Despite the county's lack of success in recent times, this sense of regional superiority and desire for ethnic purity continues. As recent as April, 2010 YCCC's current captain, Andrew Gale, admitted he holds ambitions of leading a side of players born exclusively in the county. Speaking to the Guardian about the current squad, Gale remarked:

'We've been brought up in Yorkshire, we know all about the tradition and the pride, and I'd love to see the day when once again we will field 11 Yorkshiremen. I dream of leading out a team of players born and bred in the county'. (Hopps 2010)

There is a danger of these comments being interpreted as racist. However, it is crucial to note that the squad of players Gale refers to already includes four British Asians (Adil Rashid, Ajmal Shahzad, Moin Ashraf and Azeem Rafiq) and therefore, Gale's ambition reflects his pride for the county and the work undertaken to cultivate local talent, rather than the kind of ethnic absolutism the club has previously been criticised for. Indeed, many of the British Asian respondents believed that the representation of British Asians in YCCC teams was positive and that there were grounds to be optimistic about long-term equality. Ali for instance said:

"I am proud to see players like Adil (Rashid) coming through. Such instances of achievement should be held up to show Asians that they do have a chance in this county." (Interview, March, 2009)

Due to dominant claims that British sport is meritocratic and that recruitment and selection procedures are 'colour-blind', an increasingly widespread perception has emerged - within the sport itself, among politicians and in sections of the media - that the growing numerical representation of British Asians in English cricket signifies the eradication of racism from the sport. I argue elsewhere (Author In Press) that it would be easy to accept these figures as a sign of cricket's inclusivity. However, representation is not the equivalent to acceptance and integration. The inclusion of British Asian players at YCCC is certainly not definitive of YCCC's changing mentality, as YCCC has never fielded a Yorkshire-born Black cricketer and, as a result, Yorkshire cricket continues to struggle to 
shake off its racist image; to the point where some club representatives feel YCCC's promotion of South Asian players is an act of outright desperation (ibid.).

Common representations of 'Yorkshireness' and YCCC as racist and exclusionary are deeply rooted within cricket folklore. However, there is nothing fundamentally about these representations that means they are fixed. 'Yorkshireness', for example, is a social construction; a hegemonic interplay between those transmitting the messages and those receiving and internalising them. As this paper has argued, it is also subject to changing temporal and spatial manifestations. For Chris Searle (2001), responsibility for creating and maintaining the passages of racism and exclusion should lie predominantly with YCCC's past players because they never tried to challenge the Yorkshire chauvinism and thus, facilitated its diffusion into YCCC's wider structures. Sutherland's John and Aylesworth's Rio (25, restaurateur) offered similar views:

John: 'Whenever I have read something on Yorkshire [CCC] and old players, I can't help but think what a bad image they paint of Yorkshire. I mean, [Fred] Trueman is a hugely sexist and racist man. And people of his generation looked up to him for being that person. My grandad doesn't have a bad word to say about the man. In fact, he idolises him'. (Interview, October, 2008)

Rio: What message are we sending to young people when we allow the likes of [Geoff] Boycott, [Ray] Illingworth and [Brian] Close to be the faces of Yorkshire cricket? How does YCCC expect to engage with young Asian people when the exemplars of the Club are bigots?' (Interview, June, 2009)

Geoffrey Boycott in particular, is renowned for exhibiting a controversially blunt form of 'Yorkshireness'. Boycott is venerated on the Indian subcontinent for his roles as a commentator and coach. However, this respect is not necessarily reciprocal, with many writers and commentators having reflected on Boycott's racial prejudices. Journalist Henry Blofeld, for instance, has openly criticised Boycott's treatment of Pakistani waiters: 'He calls all Pakistani waiters George and says, "George, you've got the brains of a bloody chocolate mousse." And it's not in a friendly manner' (cited in McKinstry 2001: 291). A typical characterisation of this type of behaviour is that Boycott avoids being judged because he is a Yorkshireman and Yorkshiremen are expected to be straight talkers, rash and bad mannered. Stephen Wagg (2003/04: 87) comments that 'Boycott the brand is essentially an unintended pastiche of the blunt, muck-or-nettles Yorkshire male stereotype'. This does not, however, make such remarks any less significant. Many forms of cultural racisms are expressed with a sense of irony; in a way that allows the perpetrators to deny malicious intent (Bonilla-Silva 2006). Indeed, 'it is often within humour that a culture reveals its deepest secrets' (King 2004: 1). A great deal of racist talk, for instance, is prefaced with the all-encompassing 'T'm not racist, but...' statement. And when this kind of talk is unchallenged (as is often the case with Boycott and others) it reveals the deeply embedded normative 'whiteness' of the (Yorkshire) cricketing establishment and the institutionalised racism that exists therein (Carrington 2011). The vast majority of both the white and British Asian respondents acknowledged that 
racism was an unspectacular aspect of amateur cricket in Yorkshire. As has previously been the case, the majority likened overt racial abuse to playful banter, sledging, or a form of one-upmanship. Aylesworth's Immy (25, call centre worker) and Sutherland's John commented:

Immy: 'I've experienced racism a few times and nothing really ever happens. I'm not saying it's taken for granted, but it is almost part of cricket ... it's like sledging ... I don't think it's right and it's not something I shake off easily, but I've certainly heard people call others "Black bastard" or "fucking Paki" or whatever when things aren't going their way. I don't think it's right, but it does exist, definitely.' (Interview, March, 2009)

John: Of course racism exists ... If I want to pick on someone, I'm gonna pick on the thing that's easy to pick on ... if it was [Name] I'd call him a "fat bastard" because he's fat ... that's the thing that stands out about him and if I wanted to pick on an Asian, the thing I'd pick on ... obviously because I'm English and white and he's not, I'm going to call him a "Paki" ... because they're different. If I'm playing against [player] and I get pissed off with him, I might call him a "Paki bastard" by accident ... But I wouldn't mean it, I'd just be pissed off with him and want to abuse him and that'd probably be the first thing that came to mind ... but there's not necessarily anything in it ... you're just going to pick the thing that makes them different to you, i.e. fat, Asian whatever.' (Interview, October, 2008)

For Immy and John, the prevalence of racist and abusive language was such that players often did not consider it to be 'racist'. This is not to deny the significance of the presence of racism. Racism within cricket occurs with such regularity that it is often taken for granted and viewed without criticism. There are serious issues here that neither Immy nor John acknowledged. This is not to say they were unaware of them. It has been argued that a 'conspiracy of silence' exists in cricket (Malcolm, 2002). Sport is surrounded by an 'institutional ambivalence' that effectively condones certain forms of racism through its lack of action. It is institutions like sport that legitimate these actions and embed them in what become seemingly benign practices - likening racism to sledging for example. Despite Immy and John's reluctance to engage with the seriousness of racism in Yorkshire cricket, Long et al. (1997b: 33) identify the debilitating effect YCCC's exclusionary legacy has had on its relationship with the region's minority ethnic communities:

With a team like Yorkshire that draws such strength from its historical legacy it is not surprising that some of the adverse images of the past also live on. YCCC might be trying to make amends [now], but until they acknowledge the unwelcoming attitudes of the past they are likely to be treated with suspicion by people from minority ethnic groups'.

For many minority ethnic communities, Yorkshire cricket is represented by the County Club (and everything it has stood for), which has not historically welcomed their involvement. Strikingly 
very few ethnic minorities support YCCC and even fewer attend live matches. Moreover, it has been argued that highly skilled minority ethnic players are reticent about trialling for the club on the basis that, regardless of their abilities, they would not get selected (Author In Press). It was common for respondents involved in this research to identify how YCCC was only interested in recruiting 'acceptable' players who embody the right kind (perceived to be white) of 'Yorkshireness' . Perceptions of this varied amongst the white and British Asian respondents. The white traditionalists were keen to defend the efficacy of YCCC's birthright policies and the club's tendency to recruit 'acceptable' players. Rather than accepting their innate chauvinism, they preferred to focus on their potential to build regional pride, a sense of honour and reinvigorate a sense of community. In contrast, the British Asian respondents honed in on the policy's exclusionary reputation:

Ali (36, teacher): 'For me, that policy was racist ... It was biased against Asian people and, in many ways, is why I don't identify myself with YCCC. I cannot forget the way YCCC has treated Asian people'. (Interview, March, 2009)

Inzy (25, restaurateur): 'There were Asian people who were born in Yorkshire well before the policy was stopped. Why didn't any of them play for YCCC? I'll tell you why ... that policy wasn't about being Yorkshire-born, it was about people being white. There were quality Asian players in Yorkshire well before Ajmal (Shahzad) and Adil (Rashid) were chosen to play. Was there something wrong with these people?' (Interview, February, 2009)

The majority of respondents acknowledged that YCCC did prefer a certain type of player and therefore, may not necessarily select players on their abilities alone. Most of the white respondents were frustrated about this, but had grown to accept it. In contrast, the majority of the British Asian respondents did resent what they viewed as a 'white legacy' at YCCC. Aylesworth's Zahar (26, student mentor) and Azzy (26, call centre worker) for instance, reflected upon their negative experiences of representing YCCC as juniors:

Zahar: 'I remember playing for Yorkshire when I was seventeen. It was horrendous. I got no support whatsoever. I made a fifty in one match, right, and no one even bothered to clap me. I remember my father after the game saying that I couldn't play for Yorkshire any more. He believed that them not clapping was a sign that I wasn't welcome. I still talk to my brother about it and he always says the same: "I don't know why you bothered trying”". (Interview, February, 2009)

Azzy: 'I'd love to ask the Yorkshire board: "what's the problem? Is it the colour of our skin? Is it our talent? Are we doing something wrong?" To this day I don't have a legitimate answer to that, from anyone. I don't think there is an answer if I'm honest. I think they'd be too ashamed to give you an honest answer because it's clearly about racism'. (Interview, June, 2009) 
Whilst there is growing opinion that YCCC is 'colour blind' a popular perception remains (amongst older generations of South/British Asians) that progression at YCCC is harder for ethnic minorities than it is for white people. This view is the result of generational conflict, where first and second generation migrants have grown to see Yorkshire as a 'white space' that actively buttressed an ethnocentric culture of exclusion (Long et al., 1997b). Addy, for instance, discussed how, when he was growing up, his father and grandfather openly discarded his chances of playing professionally for YCCC:

'A lot of this [ill-feeling] is down to the older generations. They're constantly saying, “they [YCCC]'ve not had an Asian cricketer for years, why do you think you'll be any different?" I used to get that all the time when I was a kid ... they'd be like, "look at the history ... there's no Asians at Yorkshire" ... "why are you wasting your time playing cricket because you're not going to get anywhere." But I had a dream back then ... when I was younger I felt like I could do it. But when you get into the real world, it's pointless. It's not about your talent ... it's about where you come from and the colour of your skin'. (Interview, March, 2009)

These experiences are clearly damaging for YCCC; especially as YCCC desperately needs to encourage the development of local talent from minority ethnic communities. The experiences of these British Asian respondents are by no means unique, but they do have wider repercussions for the game.

It is common for people outside the county to place negative interpretations on certain forms of 'Yorkshireness' that insiders deem to be desirable. YCCC's birthright policy is particularly poignant in this respect because of how it divides opinion between cultural groups. For respondents who advocated the policy's positive roles, its abolition was indicative of a changing cricket culture in Yorkshire, and a changing region generally. It was not necessarily the way they wanted it, however. Sutherland's Rocco (23, student) for example, spoke of how he preferred to see 'proper' Yorkshire lads playing for the club:

'I'd love to see that [birthright policy] back because the more people you get playing from outside the club the more you lose your identity and the less traditional values you keep ... The further up the system you go - in football especially - the more it seems to be that clubs just want the best players. They don't care where they're from. They don't care where they've been or what their value system is; they just want the best players. I'm more traditional, I'd prefer to see proper Yorkshire lads representing Yorkshire [CCC]'. (Interview, October, 2008 emphasis added)

Rocco's comments are defensive - he later remarked of the need to protect his 'patch' and maintain the boundaries against infractions by Other 'non-Yorkshire' groups. This relates to John Clarke's (1976b) argument that 'group self-image' is formed 'not simply through the internal processes 
of the group' but in relation to 'significant groups of others'. The imagined community of Yorkshire cricket is 'bounded' by a northern, white masculinity, and it is well cited that those who embody these identities are keen to protect their heritage by denying many ethnic minorities access to the imagined community (Author, In Press). However, it must be understood that this defensiveness does not revive the community in a 'real' sense; the progressive decline of any stable basis for 'Yorkshireness' has removed it as a real source of solidarity (Clarke, 1976a; Fawbert, 2011). Instead, the symbolic image of 'Yorkshireness' now forms the basis for identity definition. According to Clarke, the current generation of Yorkshire people may be referred to as 'dispossessed inheritors' on the basis that they have received a tradition which has, due in main part to migration and globalisation, been deprived of its real social basis (ibid: 100). In this case, if Yorkshire cricket allows access to minority ethnic players, supporters and administrators, it must accept that its culture will change.

\section{Conclusion}

This paper has argued that 'Yorkshireness' revolves around a highly symbolic sense of northern white masculinity and that British Asian (and British Black) people are not seen as part of this normalised imagined community (Anderson 1983; Cohen 1985). Although Yorkshire cricket (and cricket generally) has been multiracial for decades, evidence from this paper shows that some people's position as insiders is more straightforward than others. 'Yorkshireness' has traditionally stood proud, not for its mixed culture and egalitarian practices, but for a 'reified, hollow culture of boastfulness and bigotry' (Marqusee 1994: 144). There is some evidence that Yorkshire cricket has abandoned much of its historical bigotry and begun to embrace cultural diversity. Yet, popular opinion about the region and Yorkshire people continues to be heavily based on stereotypes depicting Yorkshire as highly insular and bedevilled by racism.

In conceptualising this 'imagined' community this paper has relied heavily on popular stereotypes and caricatures of Yorkshire culture and Yorkshire people. Such representations are heavily influenced by myth and invented tradition, and while not everyone in/from Yorkshire will necessarily believe these representations accurately reflect their social identity, they have been, and continue to be, simply part of our everyday lived reality of Yorkshire and Yorkshire cricket. Stereotypes are not neutral, however. They are historical formations (or invented traditions), which have an inherent power dimension linked to questions of control (Long et al., 1997a). The testimonies in this paper have done little to challenge these invented traditions (Hobsbawn and Ranger 1992[1983]), though it should be stressed that these were an expression of the interests, experiences and values of ordinary people and it was important their views were expressed in the way they had intended. Nevertheless, a critical reading of racial politics in sports cultures demands that we look with and from a different angle, especially at those accounts and histories that, in romanticising the nostalgia of white 'northern-ness', we end up disavowing the racially complex present in order to correct the official colourless distorted view of the past (Carrington 2009: 125). The key to greater understanding therefore, is in learning to look beneath the clichés and habits of imagination that lie at the heart of these myths, to see the lived realities of ordinary people. 
In twenty first century Yorkshire the current generation of young people are undertaking personal identity projects in order to redefine the region and what it means to be a Yorkshire person. Many young people, regardless of their ethnic backgrounds, do not/cannot relate to traditional stereotypes of 'Yorkshireness' because the Yorkshire they inhabit, and the Yorkshire people they socialise with, are not representative of them. Many are also unaware of these common stereotypes, whilst many who are aware are determined to construct their own contemporary identities that more successfully represent their 'cultural region'. This is arguably less of a consideration for white people because they have relative freedom to enter spaces of Yorkshire (including cricket) as unquestioned insiders because their 'whiteness' provides them with a shared social history and habitus (Ratna 2008). However, as British Asians have not historically been associated with this habitus, manipulating markers of 'Yorkshireness' and shared culture is essential to their inclusion.

Many of the issues raised in this paper have a wider bearing on how we understand the politics of racial identities in sports cultures. The inclusion of minority ethnic communities should not be based on the kind of hierarchy of acceptability, as defined by white people, evident in much of this paper. There has been a tendency for people in sport to possess rather jaded perceptions of its colour-blindness, and thus, they are reluctant to confront the fact that racism is endemic. Cricket (and sport generally) has a great opportunity to engage with young people from South/British Asian communities who may feel stigmatised by, and marginalised from, mainstream society. The only way it can do this is by embracing and accepting diverse cultures and traditions. For sports cultures to be truly egalitarian, the ideology of sport itself has to change. True equality will only ever be achieved within a de-racialised discourse which "means not investing skin colour with any meaning. To refer to colour [is] to be 'racial"' (Back, 1993: 225).

\section{Notes}

${ }^{1}$ For further discussion, see Ben Carrington's (2009) chapter 'Leeds and the topographies of race' where he provides a critical analysis of Richard Hoggart's The uses of literacy, E.P. Thompson's The Making of the English Working Class and Kester Aspden's The hounding of David Oluwale - all of which explore northern working class culture throughout the 1950s.

2 The term South Asian is used to broadly delineate people from the Indian subcontinent. The term British Asian is similarly used to delineate individuals of South Asian descent who were either born in Britain, or whom have migrated to Britain and have British citizenship.

${ }^{3}$ The exact number of cricket clubs in the UK is difficult to ascertain, but the ECB website states that there are around 8,000 cricket clubs in the UK affiliated with the ECB, with at least another 2,000 clubs not being affiliated. Most of these clubs will have a series of senior and junior teams; not to mention people who support and follow them.

${ }^{4}$ Daniel Burdsey's work on British Muslim professional cricketers has gone some way to address this, but it remains the case that amateur British Asian cricketers' voices remain marginalised.

${ }^{5}$ All participants involved in the research were encouraged to choose the name by which they wished to be recognised. This was done in order for respondents to feel a sense of ownership of their voices and their part in the research. In addition, applying pseudonyms randomly or comically - as is common where writers may impose ironic names to describe certain participants - is not necessarily appropriate for all cultural groups. Aarti Ratna (2011) argues of the importance of, and complexity behind, naming children of South Asian descent, for instance, and acknowledges that names, randomly applied, and out of context could cause offence.

${ }^{6}$ For further discussion of the methodological issues associated with this research, see Author (2010). 
${ }^{7}$ This is perhaps a methodological issue rather than a theoretical one. Stone's early analysis relied heavily on questionnaire data which, with the addition of interview and ethnographic data, would convey a greater appreciation of Yorkshire identity.

${ }^{8}$ Cricket has a long and well documented history of inequality (Holland, et al., 1996). Women and ethnic minorities, for instance, are less than subtly excluded from representations of 'Englishness' and, where they are represented, they often occupy partial statuses (Velija, 2010; Velija and Malcolm, 2009). For all its democratic utterances, historically, English cricket has remained the domain of the white male elite. It is not my intention to contribute to this subordination. Participation of women in this research has not been overlooked per se. While the study does not specifically discuss women at any length, it does not seek to marginalise them and does recognise they are important in identity discourse. In spite of this questions could be raised as to who was and who was not heard through this study. That said, the focus is on males because performance of 'race' and ethnicity is normalised as 'masculine' (Carrington, 2008; Spracklen, 2001).

${ }^{9}$ Cricket's administrators are drawn largely from the southern counties - a point which has frequently caused discontent amongst many Yorkshire people who feel their county's involvement in the governance of English cricket is subordinate as a result. The headquarters of English cricket is symbolised by Lord's and the MCC in Middlesex. The very nature of its geography is often perceived in the north to be a bastion of southern privilege, and afforded a degree of resentment.

\section{References}

Allen, L. (2008) What's so special about Yorkshire? Accessed 5 August, 2008, http://news.bbc.co.uk/1/hi/magazine/5234444.stm.

Anderson, B. (1983) Imagined Communities: Reflections on the Origin and the Spread of Nationalism. London: Verso.

Author (2010). "Being Inside and Outside the Field". An Exploration of Identity, Positionality and Reflexivity in Inter-racial Research.' In D. Chatziefstathiou and L. Mansfield (eds) Leisure Identities and Authenticity. LSA Publication No. 107. Eastbourne: Leisure Studies Association.

Author. (2011a) “The Making of English Cricket Cultures": Empire, Globalisation and (post) Colonialism.' Sport in Society 14, No. 1: 17-36.

Author. (2011b) "Who do 'they' cheer for?" Cricket, diaspora, hybridity and divided loyalties amongst British Asians. International Review for the Sociology of Sport, published online before print, July 29.

Author. (2011c) 'Yorkshire, Cricket and Identity: An Ethnographic Analysis of Yorkshire Cricket's Imagined Community.' In J. Hughson., F. Skillen. and C. Palmer (eds) Sport and Social Identity: Studies from the field. Lewiston, N.Y.: Edwin Mellen Press.

Author. (In Press) “All Yorkshiremen are from Yorkshire, but some are more 'Yorkshire' than Others": British Asians and the myths of Yorkshire cricket. To be published by Sport in Society, 2011

Back, L. (1993) Race, identity and nation within an adolescent community in South London, New Community, 19(2): 217-233. 
Ballard, R. (1994) 'Introduction: The emergence of Desh Pardesh.' In R. Ballard (ed.) Desh Pardesh: The South Asian presence in Britain. London: C. Hurst \& Co.

Birley, D. (2003) A Social History of English Cricket. London: Aurum.

Bonilla-Silva, E. (2006) Racism without Racists: Color-blind Racism and the Persistence of Racial Inequality in the United States. Maryland: Rowman and Littlefield.

Bramham, P., and Wagg, S. (2009) Introduction. In P. Bramham and S. Wagg (eds) Sport, Leisure and Culture in the Postmodern City. Surrey: Palgrave.

Burdsey, D. (2010a) 'British Muslim experiences in English first-class cricket.' International Review for the Sociology of Sport 45, No. 3: 315-334.

Burdsey, D. (2010b) 'Midnight's Grandchildren at the MCC: British Asians, Identity and English First-class Cricket.' In C. Rumford and S. Wagg (eds) Cricket and Globalization. Newcastle upon Tyne: Cambridge Scholars Press.

Burton, R. (1991) Cricket, Carnival, and Street Culture in the Caribbean, in G. Jarvie (ed.) Sport, Racism, and Ethnicity. London: Falmer Press.

Carrington, B. (1998) Sport, masculinity and black cultural resistance, Journal of Sport and social Issues 22, No3: 275-298.

Carrington, B. (1999) 'Cricket, Culture and Identity: an Ethnographic Analysis of the Significance of Sport within Black Communities'. In. S. Roseneil., and J. Seymour (eds) Practising Identities: Power and Resistance. London: MacMillan Press.

Carrington, B (2008) “What's the footballer doing here?" Racialised performativity, reflexivity and identity, Cultural Studies $\Leftrightarrow$ Critical Methodologies 8, No 4: 423-452.

Carrington, B. (2009) 'Leeds and the topographies of race: In six scenes.' In P. Bramham and S. Wagg (eds) Sport, Leisure and Culture in the Postmodern City. Surrey: Palgrave.

Carrington, B. (2011) 'What I said was racist - But I'm not a racist'. In J. Long and K. Spracklen (eds) Sport and challenges to racism. Surrey: Palgrave. 
Clarke, J. (1993) Football Hooliganism and the Skinheads. Stencilled occasional paper. Centre for Contemporary Cultural Studies: University of Birmingham.

Clarke, J. (1976a) 'The Skinheads and the magical recovery of community.' In J. Clarke, S. Hall, T. Jefferson and B. Roberts (eds) Resistance through Rituals: Youth Subcultures in Post-war Britain. London: Routledge.

Clarke, J. (1976b) 'Style'. In J. Clarke, S. Hall, T. Jefferson and B. Roberts (eds) Resistance through Rituals: Youth Subcultures in Post-war Britain. London: Routledge.

Cohen, A. P. (1985) The Symbolic Construction of Community. London: Tavistock.

Fawbert, J. (2011) 'Wot, No Asians?’ West Ham United Fandom, the Cockney Diaspora and the New east Enders. In D. Burdsey (ed.) Race, Ethnicity and Football: Persisting Debates and Emergent Issues. London: Routledge.

Guha, R. (2002) A Corner of a Foreign Field: The Indian History of a British Sport. London: Picador.

Hobsbawn, E. and Ranger, T. (1992[1983]) (editors) The Invention of Tradition. Cambridge: Cambridge University Press.

Holland, B., Jackson, L., Jarvie, G., and Smith, M. (1996) Sport and racism in Yorkshire: a case study. In J. Hill., and J. Williams (eds) Sport and Identity in the North of England. Keele: Keele University Press.

Hopps, D. (2010) Captain Andrew Gale would welcome return to Yorkshire-born tradition, accessed 25 May, 2010, http://www.guardian.co.uk/sport/2010/apr/19/andrew-gale-yorkshire-county-cricket

Hughson, J. (1997) The Bad Boy Blues and the 'Magical Recovery' of John Clarke. In G. Armstrong and R. Giulianotti (eds) Entering the field: new perspectives on world football. Oxford: Berg.

Hughson, J. (2009) Cultural History and the Study of Sport, Sport in Society 12, No. 1: 3-17.

Hughson, J., Inglis, D., and Free, M. (2005) The Uses of Sport: A Critical Study. London: Routledge.

Kalra, V.S. (2000) From Textile Mills to Taxi Ranks: Experiences of Migration, Labour and Social Change. Aldershot: Ashgate.

King, C. (2004) Offside Racism: Playing the white man. Oxford: Berg. 
Light, R. (2009) 'In a Yorkshire Like Way': Cricket and the Construction of Regional Identity in Nineteenth-century Yorkshire, Sport in History 29, No. 3: 500-518.

Long, J., Carrington, B., and Spracklen, K. (1997a) 'Asians cannot wear turbans in the scrum': explorations of racist discourse in professional rugby league. Leisure Studies, 16: 249-259.

Long, J., Nesti, M., Carrington, B. and Gilson, N. (1997b) Crossing the Boundary: A study of the nature and extent of racism in local league cricket. Leeds: Leeds Metropolitan University Working Papers.

Maconie, S. (2008) Pies and Prejudice: In search of the North. Reading: Ebury Press.

Malcolm, D. (2002) 'Clean bowled?' Cricket, racism and equal opportunities, Journal of Ethnic and Migration Studies 28, No. 2: 307-325.

Malcolm, D. (2009) 'Malign or Benign? English National Identities and Cricket.' Sport in Society 12, No. 4-5: 613- 628.

Marqusee, M. (1994) Anyone but England: Cricket and the National Malaise. London: Verso.

McDonald, I., and Ugra, S. (1998) Anyone for cricket? Equal opportunities and changing cricket cultures in Essex and East London. London: University of East London Press.

McKinstry, L. (2001) Boycs: The True Story. UK: Partridge Press.

Office for National Statistics (2001) Retrieved from http://www.statistics.gov.uk/census2001/profiles/commentaries/ethnicity.asp

Ratna, A. (2008) British Asian females' racialised and gendered experiences of identity and women's football, unpublished $\mathrm{PhD}$ Thesis, Chelsea School: University of Brighton.

Ratna, A. (2011) Flying the Flag for England? National Identities and British Asian Female Footballers. In D. Burdsey (ed.) Race, Ethnicity and Football: Persisting Debates and Emergent Issues. London: Routledge.

Reinharz, S. (1997) Who am I? The need for a variety of selves in the field. In S. Hertz (ed.) Reflexivity and voice. CA: Sage.

Russell, D. (1996) 'Sport and Identity: The Case of Yorkshire County Cricket Club, 1890-1939.' Twentieth Century British History 7, No. 2: 206-230. 
Russell, D. (2004) Looking North: Northern England and the national imagination. Manchester: University of Manchester Press.

Sandiford, K. A. P. (1998) England. In B. Stoddart and K. A. P. Sandiford (eds) The Imperial Game: Culture, Cricket and Society. Manchester: Manchester University Press.

Searle, C. (2001) Pitch of Life: Writings on Cricket. Manchester: The Parrs Wood Press.

Spracklen, K. (2001) “'Black Pearl Black Diamonds”: Exploring Racial Identities in Rugby League.' In B. Carrington. and I. McDonald (eds) 'Race', Sport and British Society. London: Routledge.

Stone, D. (2008) Cricket's regional identities: the development of cricket and identity in Yorkshire and Surrey. Sport in Society 11, No. 5: 501-516.

Wagg, S. (2003/04) 'Muck or Nettles: Men, Masculinity and Myth in Yorkshire Cricket.' Sport in History 23, No. 2: 68-93.

Velija, P. (2011) 'Nice girls don't play cricket': the theory of established and outsider relations and perceptions of sexuality and class amongst female cricketers, Sport in Society 14, No. 1: 81-96.

Velija, P., and Malcolm, D. (2009) 'Look, it's a girl': Cricket and gender relations in the UK, Sport in Society 12, No 4/5: 629-642.

Williams, J. (1999) Cricket and England: A Cultural and Social History of the Inter-war Years, London: Frank Cass Publishers.

Williams, J. (2009) 'Fiery Fred': Fred Trueman and cricket celebrity in the 1950s and early 1960s. Sport in Society 12, No 4-5: 509-522. 